\title{
Editor's Message \\ Environmental impacts of water-resources development of enclosed basins: the case of the Dead Sea
}

\author{
Elias Salameh, Associate Editor
}

Is it not a disaster if we cannot recognize evils until they are upon us? Are we actually good planners and good decision-makers? To increase our understanding of relevant concerns for issues related to or affected by planning, the keyword of any project planning has to be "system analysis". Not doing this deprives the projects of their sustainability and, because restoration can be so expensive, the economic returns of projects become questionable.

During the last five decades, water-development projects within the drainage basin of the Dead Sea supported a major part of the increasing agricultural production necessary to meet the food demand of growing populations in Jordan, Palestine, Syria, and Israel. The projects also created jobs for hundreds of thousands of refugees moving from one place to another within the area and for migrants coming from other places in the world. Thus, the development of the water resources within the drainage basin of the Dead Sea was essential for the survival of people and will be so for future generations.

During the early and intermediate stages of development, the 1950s, 1960s, and 1970s of the last century, almost no concerns were expressed about the impacts of the water-resources development of the Dead Sea drainage basin on the ultimate base level of all the water resources of the surrounding areas, including the enclosed Dead Sea itself. This development deprived the Dead Sea of a major part of its incoming water, due to which its level continued to drop. The Dead Sea left behind its old shoreline and the nearby tourist facilities, hotels, spas, and harbors far from the water, beyond an expanse of mud flats.

One of the severest impacts of development and the lowering of the Dead Sea water level is the resulting seaward migration of the saltwater-freshwater interface.

Received: 18 June 2001

Accepted: 21 June 2001

Published online: 24 July 2001

(C) Springer-Verlag 2001

E. Salameh (ه)

University of Jordan, Amman 11942, Jobeiha, Jordan

e-mail: salameli@ju.edu.jo

Tel.: +962-6-5355000, Fax: +962-6-5348932
This caused billions of cubic meters of fresh groundwater to replace saltwater in the areas between the former and the present interface positions in order to reach a new hydrodynamic equilibrium state $\left[425 \mathrm{~m}^{3}\right.$ per $1-\mathrm{m}$ drop in sea level (Salameh and Naser 1999)]. The unique configuration of the shallow interface between fresh water and Dead Sea water (density of $1.23 \mathrm{~g} / \mathrm{cm}^{3}$ ) is only about $1 / 10$ of the equilibrium depth of the interface between fresh water and oceanic water (Yechieli 1993). This makes the underground of the newly exposed shores, especially those composed of friable salty deposits, highly vulnerable to flushing due to their instability and because of the fresh groundwater percolation caused by the retreat of the interface. The freshwater flushing causes salt dissolution and fine particle removal, resulting in the creation of underground cavities which, in turn, cause ground-surface collapses in the form of sinkholes. These collapses endanger not only people but also infrastructure, hotels, spas, and farms.

What is the problem? Is it our shortsightedness, mismanagement, ignorance, or greed that led to the disastrous condition of the Dead Sea? Has all that finally made us recognize the Dead Sea and its drainage basin as one system requiring a "comprehensive system analysis" and an "integrated program for restoration"?

The Dead Sea is not a possession of any one country in the Middle East. It is not only a possession of all the riparian countries of the Middle East, but also a world heritage site. Therefore, its use, benefits, problems, and protection should bring nations together to make the best of its uniqueness. For that, courage, wisdom, and goodwill are required in order to avoid its destruction and to reach fruitful conservation schemes. The Dead Sea disaster should serve worldwide as an example of the results of piecemeal planning despite the holistic nature of natural systems.

\section{References}

Salameh E, Naser H (1999) Does the actual drop in Dead Sea level reflect the development of water resources within its drainage basin. Acta Hydrochim Hydrobiol 27:5-11

Yechieli Y (1993) The effects of water level changes in closed lakes (Dead Sea) on the surrounding groundwater and country rocks. PhD Thesis, Weizmann Institute of Science, Rehovot, Israel, 197p 